\title{
Controlled Vocabulary and Indigenous Terminology in Canadian Arctic Legal Research ${ }^{1}$
}

Author: Nadine Hoffman, Libraries and Cultural Resources, University of Calgary, Canada

\section{Abstract}

Cataloguers apply subject headings at the time they catalogue an item. As such, newer, contemporary terms used now to describe Indigenous Peoples and cultures differ from older, historical terminology of the past. This chapter analyses appropriate contemporary and historical controlled vocabulary including Canadian Subject Headings (CSH) and indexes for case law from 1892, as well as the legal literature indexes used in Canadian legal research. Changes in library subject headings and legal index taxonomy reflect changes in social norms, database practices, legal definitions, and various jurisdictions of Indigenous Peoples, including those located in Arctic Canada. Vernacular changes for subject headings were faster to shift for the collective term describing Indigenous Peoples in Arctic Canada, Inuit who were originally called Eskimo, when compared with other Aboriginal populations, notably First Nations, originally called Indian, and Métis. Contemporary researchers of Inuit Peoples and culture are encouraged to adapt search strategies that reflect both historical and contemporary terminology to effectively retrieve relevant database results across time even when outdated search terms must be used.

\footnotetext{
${ }^{1}$ Accepted manuscript for Acadia, S. and Fjellestad, M., eds., 2020. Routledge International Handbook of Library and Information Studies for Arctic Social Sciences and Humanities.
} 


\section{Introduction and History}

Terminology used to define and describe groups of people changes over time due to new social norms and shifting perspectives of naming conventions. To locate accurate historical research materials related to Indigenous populations, researchers must understand that differing conventional terms have been used to describe collective groups of people, and organise information about them, at varied points throughout history. Examples of such change can be best illustrated by analysing contemporary and historical controlled vocabulary and library subject headings. This chapter identifies various controlled vocabulary structures and taxonomies used in Canadian law libraries. Defined by Chan (2007, p.55), subject headings are a controlled vocabulary where "the term (a word or group of words) denoting a subject under which all material on that subject is entered into a catalogue." Library cataloguers and legal indexes use subject headings to provide access to resources for researchers.

Marginalised and racist terms such as 'Eskimos,' 'Indians,' 'savages,' and 'half-breeds' were once acceptable in Canada but are now outdated and considered derogatory. The term 'Eskimo' - meaning "raw meat eaters" - originated with European explorers in the 17th century to describe Indigenous inhabitants of Canada, Greenland, Alaska, and Siberia, but has now been replaced by the term 'Inuit' in Canada (Indian and Northern Affairs Canada, Communications Branch, 2002; Library and Archives Canada, 2012). The term 'Indian' originated from Christopher Columbus believing he found India when he arrived at the new world in 1492. The first legislation using 'Indian' was the 1763 Royal Proclamation, and the term was officially defined in Section 3(3) of the Indian Act, 1876. According to Kam (2007, p.19) the colonialised origin of the term 'Indian' is "hard to ignore." The incorrect social usage of sweeping terms such as 'Indian' for thousands of Indigenous nations in the Americas, as well as 'Eskimo' for 
inhabitants in the farthest north of the North American continent has been misapplied and perpetuated across history by missionaries, governments, and non-Indigenous citizens throughout the United States and Canada (Indian and Northern Affairs Canada, Communications Branch, 2002; Indigenous Corporate Training, Inc., 2016; Library and Archives Canada, 2012).

The term 'First Nations' was coined as a preferred term by Indigenous Peoples in Canada to replace 'Indian Band' in the 1970s even though the term does not include Métis or Inuit Peoples (Indian and Northern Affairs Canada, Communications Branch, 2002). 'Inuit' is used for the Indigenous Peoples residing in the Arctic regions of Canada, while Métis refers to Indigenous Peoples with mixed ancestry of European and First Nations Peoples. Beginning with the Constitution Act, 1982, however, the term 'Aboriginal Peoples' in Canada was used as a collective legal term for all Indigenous Peoples including Indian, Inuit, and Métis. This change in legal terminology meant Canadian citizens shifted to using 'Aboriginal' as the collective term and law libraries shifted cataloguing practices similarly to those outlined by Tarulli (2007, para.6): "the best term for works collectively describing the First Nations, Métis, and Inuit was Aboriginal Peoples ... Indigenous Peoples was selected for all aboriginals residing outside of North America/Canada."

Canadian cataloguing practice changed with the 3rd edition of Canadian Subject Headings (Schweitzer, 1992) to officially shift from 'Indians of North America' as an official subject heading to 'Native Peoples - Canada,' as well as specific names of individual nation, such as Inuit and Métis. However, by the 21st century, a lack of consensus with respect to changes in terminology began to emerge. Based on survey results of Canadian academic libraries, Lee (2011, pp.26-27) noted that the term 'Aboriginal' is not objectionable even though 
academic librarians prefer 'Indigenous Peoples' while school and public libraries use 'First Nations.'

In 2008, the Truth and Reconciliation Commission of Canada (TRC) was formed as the result of the Indian Residential Schools Settlement Agreement of May 8, 2006 (Residential Schools Settlement Official Court Notice website, http://www.residentialschoolsettlement.ca/settlement.html) and their mandate included documenting the truth for future research by survivors, families, communities, and researchers (Schedule "N": Mandate for the TRC, 2006). Catholic, Anglican, and Protestant churches operated close to 140 Indian Residential Schools across Canada, and, from 1866 to 1996, these institutions forcibly removed Indigenous individuals from their local communities for confinement in boarding schools sanctioned by the Canadian government. To be sure, "these schools and residential institutions represent one of the darkest and most shameful undertakings in Canadian history" (Lougheed, Moran, and Callison, 2015, p.597).

TRC transformed Canadian Aboriginal law by outlining recommended initiatives to acknowledge and repair damage caused by colonial relations decreed by the Canadian government with Indigenous Peoples, and a 2015 TRC report began the process of indigenising research and teaching across Canada, specifically under Action numbers 6 to 12 and 62 to 65 . To indigenise is to "make indigenous; subject to native influence" (Barber, 2004). The report's recommendations led to indigenising curriculum across Canada with most post-secondary institutions creating indigenous strategies. For example, University of Calgary's Indigenous Strategy was released in November 2017 as described by Michael Hart, Vice-Provost of Indigenous Engagement, in a CTV News Calgary (2018) video interview in celebration of National Indigenous Peoples Day. 
In addition, the TRC report introduced Action numbers 67 to 70 in its Museums and Archives section that specifically relate to libraries. The report was timely in recognising the need for attention in libraries; in the same year that it was published, Lougheed, Moran, and Callison (2015, pp.605-606) identified barriers to library services by Indigenous users, stressing that the "importance and validity of a dynamic culture of oral traditions, and issues of decolonization and re-empowerment $\ldots$ in order to overcome these barriers in working with primary, archival materials." Two years later, the Canadian Federation of Library Associations (CFLA) published a 2017 report containing library-specific recommendations to help decrease these barriers.

Following the TRC report, a public opinion poll conducted by the Environics Institute for Survey Research (2016) suggested that the term 'Indigenous Peoples' is most likely to be used across Canada in the future even though 'Aboriginal' is familiar and recognisable. Results of the poll (p.3) concluded that 'Aboriginal' " $\ldots$ has been the primary term used in both legal and popular contexts until very recently and is now in the process of being replaced by the term 'Indigenous' as a more appropriate term and one consistent with the United Nations Declaration on the Rights of Indigenous Peoples." Yet, even in contemporary Canada, the federal department Indigenous and Northern Affairs Canada (2017, para.3) regards 'Aboriginal Peoples' as "more than 630 First Nation communities in Canada, which represent more than 50 Nations and 50 Indigenous languages" and considers it as an accepted term by all, including judges and lawyers in the legal community, politicians, and all Indigenous Peoples in Canada due to the constitutional definition. By extension, 'Aboriginal Law' describes the Canadian legal research area whereas 'Indigenous Law' describes the international context. 
During a speech in the House of Commons, Canadian Prime Minister Justin Trudeau (2018) announced a legislative framework for Indigenous Rights in Canada with the intention to move beyond the Indian Act. This announcement began the process for the Government of Canada to pass legislation in June 2019 (SC 2019, c 29) to update the long-standing Indian Act, completing the progressive move in terminology to embrace 'Indigenous Peoples' as the proper collective term even though the constitutional definition for 'Aboriginal Peoples' is unlikely to change. Notwithstanding, 'First Nations,' 'Métis,' and 'Inuit' are still most commonly used as the proper, current terms to portray distinctive Indigenous cultures in Canada (Indigenous Corporate Training, Inc, 2016) and are likely to remain so.

\section{Legal Research: Some Definitions}

Legal research is the search process using the primary sources of legislation and case law. Legislation - defined by Garner (2014, p.1038) as "the whole body of enacted laws" - includes statutes or laws, regulations, constitutions, and treaties. Legal decisions from courts and tribunals, known as case law, is used by lawyers as precedent, "a decided case that furnishes a basis for determining later cases involving similar facts or issues" (Garner, 2014, p.1366). To aid researchers by condensing legal decisions, commercial publishers produce case digests condensing decisions into annotations and contain robust indexes using unique subject classification schemes based on relevant points of law (Campbell, 1997, p. 7). Case law reporters - defined by Garner (2014, p.1493) as "an official or unofficial published collection of judicial opinions" - usually contain a subject index for researchers to find relevant cases. These brief definitions are provided here as background because the current chapter uses legal indexes and case digests to examine subject headings relating to Indigenous populations in Canada. 


\section{Controlled Vocabularies in Canadian Law Libraries}

The most commonly-used controlled vocabularies used to populate catalogue records in Canadian law libraries are Library of Congress Subject Headings (LCSH) and Canadian Subject Headings (CSH). In addition, Library of Congress Classification (LCC) is used normally in Canadian libraries to organise book shelf locations, though many law libraries in Canada have implemented the LCC-based KF Modified classification scheme since 1970 (Ginsberg, 1988, p.161; Quigley-Jones, 1994). Many commercial databases also construct their own controlled vocabularies based around LCSH or similar taxonomic structures, including author-supplied keywords that may use contemporary and specialised terminology. In this chapter, terminology

specific to the Arctic Canadian region is highlighted as a special subset of terms as they relate to Indigenous Peoples residing in the far Canadian North. The Library of Congress created LCSH in 1898 using American spelling, naming conventions, and standardisations reflective of the social norms of the late 19th century. In 1988, nearly 100 years later, a decision was made to favour specific tribal names instead of 'Indians of North America' (Library of Congress, 1988, p.84). In the 1990s, the Library of Congress moved away from the subject heading 'Indians of North America' altogether toward 'Native Peoples,' then, finally, to 'Indigenous Peoples' as of the 34th edition in 2014.

Since 1968, Library and Archives Canada (LAC; 2016, para.1) have created CSH to concentrate on "the Canadian cultural, economic, historical, literary, political, and social experience." CSH is an add-on to LCSH as explained by Tarulli (2007, para.8): "Canadian libraries face challenges. We are, in a way, married to the United States, but we are unique. We seek guidance from the Library of Congress, yet we have our own terms and our own people." Individual names of First Nations, tribes, reserves, and groups of Aboriginal Peoples in Canada 
are included in CSH. 'Inuit' is the collective heading most specific to Indigenous Peoples in the Canadian Arctic region, replacing the prior 'Eskimo.'

Discussions regarding subject headings for Indigenous Peoples increased from the late 1990s in Canada. Carter (2002, pp.8-10) is credited with writing the first article advocating for new ways of respectful subject heading assignments for Indigenous Peoples and championed to regard Indian treaties as primary legal documents in the same way that international treaties are regarded. Recommendation 10 from a 2004 LAC report stated that "the development of appropriate cataloguing and subject guides [should] be considered a priority in the long term to address the deficiencies of the current subject heading guides and cataloguing practices" in order to decrease racism through current cataloguing terminology and “....re-teach the 'experts,' such as cataloguers, about the terms used to describe Aboriginal peoples" (Blake, Martin, and Pelletier, 2004, p.23). This recommendation helped start the 2007 LAC consultations on CSH where the original proposal was to change 'Indians of North America' to 'First Nations,' 'Native Peoples' to 'Aboriginal Peoples,' and remove the word 'Indians' from tribe names (e.g., 'Sarcee' instead of 'Sarcee Indians'). In 2009, lack of consensus for terminology and concern over potential inconsistencies with LCSH led to the abandoning of LAC's 2007 proposal. LAC made the decision to "not to go ahead for now with the changes as proposed. We will instead make a start by considering changing headings for specific Aboriginal Peoples on a case-by-case basis, to see what we can do to improve access" (Library and Archives Canada, 2013, para.3).

Though LCSH has evolved over time, terminology is slow to change, and many library scholars argue that ethnic-related subject headings are archaic, outdated, biased, politically incorrect, and racist (Kam, 2007; Lee, 2011; Moulaison Sandy and Bossaller, 2017; Olson, 2002; Olson and Schlegl, 2001; Tomren, 2003; Webster and Doyle, 2008). Hope Olsen, regarded as 
"the foremost researcher on the topic of bias in subject access today, particularly as it pertains to women" (Tomren, 2003, p.4), suggested that racist and sexist historical perspectives are ingrained in Western and European worldviews that exclude "the vast universe of indigenous and traditional knowledge" relating to subject access in libraries (Moulaison Sandy and Bossaller, 2007, p.134). Similarly, Kam (2007, p.18) ascertained Indigenous subject headings as "unavoidably biased because they perceive and describe the world from a predominantly white, Christian, and European-centric perspective." The history of subject headings related to Indigenous Peoples in Canada are viewed as Eurocentric and part of colonialist ideals.

In 2017, the CFLA released a call to integrate culturally appropriate metadata respecting Indigenous Peoples into bibliographic records amongst existing terminology. As stated by CFLA (2017, pp.28-29):

Both Indigenous and non-Indigenous library and information science (LIS) professionals have long criticized the Eurocentric bias of these systems: Indigenous names for peoples and places are either not used or inaccurately Anglicized; Indigenous sovereignty and worldviews are unrecognized; almost all literature save some aspects of tribal law are classed narrowly in American history regardless of their currency; and ideologically-biased terminology renders invisible the genocides committed by colonial states against Indigenous North Americans ... Professionals must be conscious of the risk of embedding Westernized conceptions of panAboriginality into new systems.

Years earlier, Webster and Doyle (2008, pp.191, 195) advised that lack of accessibility, and arguable perpetuation of stereotypes by using incorrect or inappropriate subject headings, often leads to service quality issues in libraries and represent "significant concerns for cataloguers, librarians, and educators, and they warrant our vigilant attention." Also, librarians' credibility can be damaged through terminological misuse, abuse, and insensitivity. By using established rules, library cataloguing practices use outdated terminology that can create barriers to library use for Indigenous Peoples and scholars. 
Despite drawbacks, subject headings provide a way for library cataloguers to describe and organise materials, as well as aid researchers in finding relevant materials even when there are differences in contemporary and historical terminology. Cataloguers in the 21 st century have a responsibility to provide ethnically and culturally accurate subject headings in their work, but that has not always been the case. As such, outdated and derogatory subject terms still exist for historical materials and researchers must recognise that use of these terms in search strategies is often required. For historical indigenous topics and resources, the use by cataloguers and researchers of subject headings that were once applied more regularly, and often forgotten by researchers, may yield the most effective results for their cataloguing and research purposes. The specific terminology chosen to represent the collective group of Indigenous Peoples over time is similar in indexes as it is in controlled vocabulary in representing areas of law used in legal research.

\section{Canadian Law Indexes and Digests: An Overview}

Legal indexes help researchers find primary and secondary materials in legal research. Canada Law Book and Carswell, along with their partner publishers, are historically the main national case law publishers in Canada, in addition to Maritime Law Book, who operated from 1965 to 2016 (Campbell, 1997; Denton, 1997; Matthews, 2016); each of these companies published a subject index since their inception. The indexes have evolved over time from loose collections of case law organised by style of cause/party names, which started in the 1890s, to more detailed case reporter subject headings that began in 1935 with the Canadian Abridgment

$(C A)$. In fact, the main print indexes in Canada are part of the seven components of the $C A$. This chapter used two components of the CA: Case Digests, later called the Canadian Abridgment Digests $(C A D)$ and Index to Canadian Legal Literature (ICLL). Both publications evolved 
through multiple editions and are currently available through the proprietary legal database WestlawNext Canada. A competing proprietary database, Lexis Advance Quicklaw, uses its own electronic subject headings developed in the late 1970s for the original Quicklaw database. Not unlike LCSH, these legal indexes have been slow to change over time and "law librarians are acutely aware of the need for well-organized and up-to-date case law research materials" (Foote, 1994, p.20).

The first two examples of Canadian case digests varied by title, publisher, and editors from 1892 through 1961; publishers changed due to joint ventures and mergers while editorial boards changed regularly every two to five years. The Canadian Annual Digest (CD) (18971961) from the Canada Law Journal Company became the index used for Canada Law Book reporters such as Canadian Criminal Cases (started 1898) and the Dominion Law Reports (started 1912), whereas the multi-year digests and abridgments developed by Carswell are now consolidated into the $C A$. As of 2010, Thomson Reuters publishes both products. $C D$ is divided into natural groupings with classification tables included at the prefaces of each subject. All historical case law indexes contain a form of 'Indian' as the main subject for Indigenous Peoples where individual cases relate to constitutional law, land, or crime. Taxonomically, these indexes provide the broadest level of terminology for Canadian legal cases; thus, they do not separately identify Indigenous Peoples living in Arctic Canada.

\section{Canadian Abridgment Digests (CAD)}

The $C A D$ began as a cooperative publishing venture between Burroughs \& Company Ltd. and The Carswell Company Ltd. with the publication of 35 digest volumes in 1935 . The $C A D$ started as "comprehensive and topically organized case digests," then evolved into a multifaceted finding aid (Silverstein, 2008, p.xii). The second edition of the $C A D$ (1966) continued 
under The Carswell Company Ltd. from 1966 to 1985, comprising 43 volumes, but later grew to over 70 volumes in the reconsolidated and reclassified revised second edition from 1986 to 2003. The third edition began in 2003 with 117 volumes. The accompanying Canadian Abridgment Key allowed for the creation of broad subject headings as "a complex research tool" using unique classification schemes (Foote, 1994, p.6).

\section{Canadian Annual Digest (CD)}

Originally created in 1892 as part of the Canadian Criminal Cases by the Canada Law Journal Company, $C D$ is the oldest continuous index. The $C D$ continued under the Canada Law Book Company for the Dominion Law Reports in 1912, as well as subsequent endeavours including the All Canada Weekly Summaries in 1977 and regional reporters.

\section{Digest of Canadian Case Law (DCCL)}

The Carswell Company Ltd. first published DCCL in 1900. This title was a joint venture with the Canadian Law Book company from 1920-1925. The data from DCCL marks the beginning of the content for the $C A D$.

\section{Index to Canadian Legal Literature (ICLL)}

In 1956, "Carswell began to publish an Index of Articles from Legal Periodicals as part of The Canadian Abridgment" (Silverstein, 2008, p.xii). The comprehensive, English-French index was used to create the stand-alone ICLL beginning in 1981. The second edition began in 1987 with contributors from law libraries and features works published in Canada, including journal articles, course materials, conference materials, book reviews, case comments, and legislative commentary. Out of a cooperative venture, ICLL now has an editorial board comprised of law librarians appointed by the Canadian Association of Law Libraries (CALL) 
whose members work directly with Thomson Reuters, formerly Carswell (Campbell, 1996, pp.244-245).

\section{Index to Canadian Legal Periodical Literature (ICLPL)}

CALL established a committee in 1963 to create ICLPL for legal articles and conference proceedings by subject. Each volume includes a separate thesaurus. As an index, ICLPL helps researchers determine effective terminology for database searching. ICLPL editor Marianne Scott described the rationale for creating the index by arguing that "the Canadian Index [Canadian Periodical Index] was too general, including law only as part of the social sciences and humanities, while the Index to Legal Periodicals has never included all Canadian legal titles and, as a result, was not sufficiently inclusive" (vol. 1961-1970, Preface). ICLPL "also indexes law-related articles from selected non-legal serials and individual essays from edited collections" (Campbell, 1996, p.244). According to Chantal Lamarre, Acquisitions and Content Director at the Centre D'Accès à L'Information Juridique (personal communication), the print index ceased following the 2006 edition and became the Scott Directory under the Centre and uses CSH for its thesaurus.

\section{Maritime Law Book Index (MLBI)}

MLBI works with the National Reporter System across all Maritime Law Book reporters. The index came into existence in 1965 when the Maritime Law Book company was founded (Compass Law, 2017). MLBI includes “... a Key Number system modelled on the West Publishing Key Number System" for case law in the United States (Denton, 1997, p.36). This robust system was used by several law libraries for their memo banks and subject cataloguing. Maritime Law Book ceased print operations in November 2016, but continued under the Compass Law company (Rodrigues, 2016; Matthews, 2016; Lachance, 2017). 


\section{Terminological Analysis: Methods}

For this chapter, historical and contemporary changes in Indigenous terminology from a Canadian legal perspective were systematically analysed through an examination of five print and electronic legal indexes: (1) $C A D$ from 1935-2017; (2) CD from 1896-1944; (3) ICLL from 1981-2017; (4) ICLPL from 1961-2006; and (5) MLBI from 1976-2016. Arctic-specific terms as they relate to Indigenous peoples were highlighted at every step of the research process. These five indexes are widely used in legal research to find Canadian case law and legal literature. Smaller law libraries and firms also use these indexes to create subject access to their files, memo banks, and library resources. Although ICLL contains English and French language headings, the analysis of its subject headings was limited to those in English for consistent comparison with other indexes. This analysis comprised all historical print editions and online updates for CSH from 1966-2016, including a thorough review of all three editions of CSH, along with the CSH New and Modified Records 1992-2016 supplements and committee reports to identify changes of Indigenous terminology throughout (Canadian Library Association, Committee on Canadian Subject Headings, 1968; Canadian Library Association, Technical Services Section, 1966; National Library of Canada, 1985; Schweitzer, 2015). The literature reviewed earlier in this chapter confirmed my own knowledge of library cataloguing practices from formal training, hands-on knowledge as a cataloguing librarian, and over 20 years of experience assisting or conducting research.

The starting point for analysis was the subject heading 'Indians of North America' because this is historically the most frequently assigned main subject heading in Canada for Indigenous Peoples. Specific terminology reviewed in each edition of CSH ultimately included the following terms: 'Aboriginal,' 'Eskimo,' 'First Nations,' 'Indians,' 'Indigenous,' 'Innu,' 
'Inuit,' 'Métis,' and 'Native,' as well as various native languages and names of nations or tribes. Use of the terms 'Eskimo,' 'Innu,' and 'Inuit' ensured finding the most relevant terms to Canadian Arctic regions, while inclusion of 'First Nations,' 'Métis,' and 'Native' as terms allowed for all groups of Indigenous Peoples in Canada. Legal definitions provided the remaining terms to search: 'Aboriginal' as defined in the Constitution Act, 1982 and 'Indigenous' as used in the United Nations Convention on the Rights of Indigenous Peoples (United Nations, 2008). Given the print nature of the three CSH editions, in alphabetical order, variant forms of the terms were easily determined. The hundreds of individual subheadings related to languages, literatures, art forms, and nation names were not included because of this study's primary interest in the collective terms found in CSH. However, nation names and languages (e.g., Algonquin, Blackfoot, and Cree) from searching the CSH were included to confirm that all headings were found in the five legal indexes. While systematic analysis of CSH and ICLL preliminarily led to seven relevant subject headings at the broadest level, over 150 potential sub-headings under Indians of North America alone were identified.

I decided that conducting interviews with colleagues at legal firms and law libraries would well supplement and inform the process and results of the terminological analysis in this study. To determine appropriate colleagues to interview, I had preliminary conversations with the largest law firm libraries in Alberta. These conversations revealed that early-career colleagues confused LCC (call numbers) with subject headings (controlled vocabulary). Due to the reliance on copy cataloguing - defined by Chan as "the process of adapting an existing catalog record prepared by another library or agency" (Chan, 2007, p.543) - and the lack of access to official, firm-specific cataloguing policies and practices, a formalised survey of law firm library cataloguers exclusively would not be ideal. Instead, I chose to conduct semi- 
structured informal interviews with ten staff familiar with cataloguing at a mix of institutions: six at Canadian law firms, one at a courthouse library, and three at academic libraries in Calgary, Alberta, Canada. Some of these were colleagues already a part of my own professional network, while others were recommendations from those colleagues. I emailed potential interviewees details about this study along with a list of indexes I used to conduct terminological analysis. All ten individuals accepted my invitation to conduct interviews; eight interviews were done via the telephone and two in person. The interviews focused on determining historical cataloguing practices relating to assigning subject headings for Indigenous Peoples and were with either a senior member or retiree of their respective institutions with extensive law library experience.

The interviews for each participant included the following five questions:

1. From where did you get your copy cataloguing?

2. How did you determine your subject headings for library materials?

3. How have you seen library practices change for legal cataloguing and subject headings related to Indigenous terminology?

4. Are any indexes missing from the list of indexes to use for subject headings?

5. Can you suggest anyone else to consult regarding this research project?

Upon compilation of subject headings and completing the interviews, I completed a comparative analysis to determine similarities among and highlight differences between Indigenous subject headings generally and for the Canadian Arctic specifically. I created a table for each index or digest to list the various subject headings and sub-headings, followed by a timeline to illustrate themes and when they changed their terminology. This process found several repetitive subheadings that were removed because they overcomplicated the tables and included more detail than was necessary for this analysis. 


\section{Terminological Analysis: Results}

Like the CSH findings, all five legal indexes surveyed historically use some form of the term 'Indian' in their subject headings. This is not surprising given the Indian Act, 1876.

However, legal publishers were faster to adopt newer terms despite historical legal definitions, as evidenced by introduction of the terms 'Aboriginal Peoples' and 'Native Peoples.' At the top level, the $C A D$ shifted from headings related to 'Indigenous Peoples' under the sub-category of 'Constitutional Law' or the separate heading of 'Indians' to 'Indians and Eskimos' starting in 1970, then changed to 'Native Law' in 1999 following reissue of the second edition, and, finally, 'Aboriginal Law' with the third edition in 2003.

The most robust index for Canadian legal literature is ICLL which started the move away from 'Aboriginal Peoples' toward 'Indigenous Peoples' in 2014; however, specific topics relating to people registered under the 1985 revised Indian Act remain under 'Indians of North America' because 'Indian' is a statutory definition. Table 1 shows the indigenous subject heading changes for each revised print version of $I C L L$ with a separate column for specific Arctic subject headings. The headings provide the broadest, most general level of research in including the collective terms; therefore, this is a selected list of terms, rather than an individual list of hundreds of titles (e.g., the heading 'Indians of North America' alone has over 430 subheadings). 
Table 1: Summary of Indigenous Subject Headings from the Index to Canadian Legal Literature (ICLL, 1981-2017)

\begin{tabular}{|l|l|l|}
\hline Year & General Indigenous Headings & Arctic Indigenous Headings \\
\hline $1981-1984$ & Native People & \\
\hline $1985-1986$ & $\begin{array}{l}\text { Individual peoples, e.g., Cree Indians } \\
\text { Indians of North America with See references } \\
\text { from Indian Reservations; Indians of Canada } \\
\text { Métis with See references from Indians of North } \\
\text { America } \\
\text { Native races - Canada }\end{array}$ & $\begin{array}{l}\text { Inuit with See references } \\
\text { from Eskimos; Native races - } \\
\text { Canada } \\
\text { Inuit with See references } \\
\text { from Indians of North } \\
\text { America }\end{array}$ \\
\hline 2014 & $\begin{array}{l}\text { Aboriginal title } \\
\text { Half-breeds (Canadian Indians) See Metis } \\
\text { Indian reservations } \\
\text { Indian title } \\
\text { Indians } \\
\text { Indians, treatment of } \\
\text { Indians of North America } \\
\text { Indigenous peoples } \\
\text { Indigenous peoples (international law) } \\
\text { Metis } \\
\text { Native Canadians See Indians of North America } \\
\text { Treaty Indian reservations }\end{array}$ & $\begin{array}{l}\text { Eskimauan Indians See } \\
\text { Eskimos } \\
\text { Eskimos See Innuit; Inuits }\end{array}$ \\
\hline
\end{tabular}

ICLPL is superior for cross-referencing Indigenous Arctic terms with the term 'Inuit.'

The annual indexes first used the heading 'Inuit See Eskimos' in 1981 followed by 'Eskimos See Inuit' in 1990. The move to 'Aboriginal Peoples' in 1992 led to indexed materials under Indians specifically relating to the Indian Act. The indexed materials in 2002 changed to reflect taxation, legislation, reserves, agency developments in Aboriginal law, decisions, governance, or status under the Indian Act. Table 2 is adapted from a thorough analysis of the Thesaurus and Subject Headings of ICLPL throughout the print publication. Terminology related to Indigenous Peoples progressed over time, ending in 2006 when the index ceased in print. 
Table 2: Summary of Indigenous Subject Headings from the Index to Canadian Legal Periodical Literature (Scott, 1961-2006)

\begin{tabular}{|c|c|c|}
\hline Year & General Indigenous Headings & Arctic Indigenous Headings \\
\hline 1961-1970 & Indians & Eskimos \\
\hline 1971-1975 & $\begin{array}{l}\text { Native rights See also Names of } \\
\text { specific aboriginal inhabitants, e.g. } \\
\text { Eskimos }\end{array}$ & $\begin{array}{l}\text { Native rights See also Names of specific } \\
\text { aboriginal inhabitants, e.g. Eskimos }\end{array}$ \\
\hline 1981 & & Inuit See Eskimos \\
\hline 1983 & Aboriginal rights See Native rights & \\
\hline 1984 & Métis & \\
\hline 1990 & & $\begin{array}{l}\text { Inuits } \\
\text { Eskimos See Inuits } \\
\text { Native rights See also Names of specific } \\
\text { aboriginal inhabitants, e.g. Inuits }\end{array}$ \\
\hline 1992 & Aboriginal peoples & \\
\hline 1994 & $\begin{array}{l}\text { Aboriginal peoples See also Indians; } \\
\text { Inuits }\end{array}$ & $\begin{array}{l}\text { Aboriginal peoples See also Indians; } \\
\text { Inuits }\end{array}$ \\
\hline 2001 & $\begin{array}{l}\text { First nations See Aboriginal peoples } \\
\text { Indigenous culture } \\
\text { Indigenous peoples See Aboriginal } \\
\text { peoples }\end{array}$ & Inuits See also Montagnais \\
\hline 2002 & Nisga'a & \\
\hline 2003 & Chippewas & \\
\hline 2005 & $\begin{array}{l}\text { Native peoples See Aboriginal } \\
\text { peoples }\end{array}$ & Innus \\
\hline
\end{tabular}

The Canada Law Book Company produced the $C D$ from 1892-1961. Table 3 shows the changes in subject headings related to Indigenous Peoples. Arctic peoples were not indexed as separate subject headings. $D C C L$, published by The Carswell Company Ltd., did not include Arctic-specific subject headings, but there were two main headings for Indigenous Peoples from 1901-1905: (1) 'Indian’ where sub-headings include ‘Claim for Restitution of Moneys to Trust Fund,' 'Half-breed,' and 'Intoxicating Liquor' and (2) 'Indian Lands' where sub-headings include 'Sale of Timber' and 'Sale or Lease.' The updated edition of $D C C L$ published in 1910 
shifted to 'Indians' to encompass both headings. The later joint venture with the Canadian Law Book Company continued using 'Indians.'

Table 3: Summary of Subject Headings from The Canadian Annual Digest (Canada Law Book, 1892-1961)

\begin{tabular}{|l|l|}
\hline Year & Summary of Headings \\
\hline $1892-1925$ & Indians See also Intoxicating Liquors \\
\hline 1897 & Indian Treaties See Constitutional Law, III “Miscellaneous Cases” \\
\hline $1920-1925$ & Indians \\
\hline $1935-1944$ & $\begin{array}{l}\text { Indians See also Criminal Law; Crown Lands } \\
\text { Crown Lands-Dominion Lands; Indian Reserves }\end{array}$ \\
\hline 1961 & Indians See also Criminal Law; Crown Lands \\
\hline
\end{tabular}

Four of the six law firm interviewees described $M L B I$ as a great source for terminology used in original cataloguing and firm memo banks. Therefore, I consulted Colin Lachance, the Chief Executive Officer of Compass Law, the company who publishes MLBI since 2016, to find out which $M L B I$ subject index would be recommended for comprehensiveness in this research. Lachance (personal communication, 17 May 2017) recommended using MLBI's Alberta Reports index as it contains comprehensive subject headings for Indigenous Peoples. Table 4 shows that the term 'Inuit' at the broadest level in the Alberta Reports first appears in 1992. MLBI is the sole Canadian index for case law to include the words 'Inuit' and 'Métis' at the most general level as seen in the heading 'Indians, Inuit and Métis' that existed when print ceased in 2016. Table 4 also shows more sub-headings than those from the other indexes to illustrate how $M L B I$ used advanced taxonomic structure, including more numerous terminologies relating to Indigenous Peoples throughout its lifespan. 
Table 4: Summary of Maritime Law Book Index Subject Headings (Index, Alberta Reports, 1976 -2016)

\begin{tabular}{|l|l|l|}
\hline Year & General Indigenous Headings & Arctic Indigenous Headings \\
\hline $1976-1990$ & $\begin{array}{l}\text { Indians: Rights; Nations, Tribes and Bands; } \\
\text { Treaties and Proclamations; Lands; Government } \\
\text { of Indians; Taxation }\end{array}$ & \\
\hline $1992-1993$ & Indians, Inuit and Métis & Indians, Inuit and Métis \\
\hline 1994 & Sub-heading: Aboriginal Rights & \\
\hline 1994 & $\begin{array}{l}\text { Sub-heading: Particular Aboriginal or Treaty } \\
\text { Rights }\end{array}$ & \\
\hline 1997 & $\begin{array}{l}\text { Sub-heading change from Government of Indians } \\
\text { to Government }\end{array}$ & \\
\hline 2013 & $\begin{array}{l}\text { New sub-heading: Indian Residential Schools } \\
\text { Settlement Agreement }\end{array}$ & \\
\hline
\end{tabular}

All ten interviewees described the need to use 'Indian' for indigenous-related terminology, particularly for historical purposes. At the same time, some noted that such terminology was particularly problematic for reasons already covered in this chapter. Some interviewees confirmed that beginning this terminological analysis with the term 'Indian' and describing the transition to 'Aboriginal' as paralleled with 'Eskimo' to 'Inuit' was a sound research strategy. Additionally, all noted that the transition to 'Inuit' occurred faster than that from 'Indian.' Interestingly, the three retired interviewees of this study had no opinion on the move to 'Indigenous,' while the other seven currently-employed interviewees were optimistic and determined about the eventual likelihood of occurring. Five interviewees agreed that review of individual nation names in each index was critical for thoroughness.

\section{Discussion}

The analysis of all five legal indexes and the $\mathrm{CSH}$, along with interviews, illustrates changes over time in legal terminology and cataloguing practise in Canada. The indexes and 
CSH analysed show evolving social vernacular toward respect of Indigenous Peoples in Canada. Retzlaff (2005, p.613) described the overarching collective terms as "the shifting membership categories in Native discourse, e.g., replacing 'Indian' with 'Aboriginal,' 'Native' and 'First Nations' shows that discourses are dynamic, and that these shifts reflect wider processes of socio-political changes."

The shifting terminology from 'Eskimo' to 'Inuit' likely happened faster than for other Indigenous Peoples in Canada, likely due to the later timeframe of integrating the Inuit populations into colonised Canadian society starting in the 1930s when Canadian government authorities began examining the Arctic region and concentrations of Inuit communities (Borrows and Rotman, 2012, p.595). This rapid shift occurred despite the conflicting legal history of Inuit Peoples, whereby they are constitutionally included as Indians or Aboriginal Peoples of Canada in accordance with the British North America Act, 1867 and Constitution Act, 1982 but “... specifically excluded from the scope of the federal Indian Act (Borrows and Rotman, 2012, p.595).

Each of the indexes shows similar terms in their controlled vocabulary and changes with social vernacular and legal definitions. The swift move from 'Eskimo' to 'Inuit' was complete by the 1990s, whereas the move from 'Indian' began only in the 1980s and 'Indians of North America' remains even in 2018 as the term for persons with status under the Indian Act. The recognition of Métis Peoples changed from 'Indians of North America-Mixed descendent' throughout the 1970s and 1980s. Changes in Arctic-specific CSH are reflective of the creation of Nunavut, a territory that officially came into existence in Canada on April 1, 1999. The Nisga'a Final Agreement, ratified in 1999 and taking effect the following year, coincided with CSH by 
adding reserve numbers as part of individual subject headings. Table 5 documents specific chronology for subject headings related to the Arctic in CSH.

Table 5: Canadian Subject Headings for Indigenous Peoples (1966; 1968; 1985; 1992; 1999; 2017)

\begin{tabular}{|c|c|c|}
\hline Year & General Indigenous Headings & Arctic Indigenous Headings \\
\hline 1966 & $\begin{array}{l}\text { Indians of North America - Canada } \\
\text { Indians of North America - Mixed bloods } \\
\text { Metis - Canada [Manitoba, etc.] }\end{array}$ & $\begin{array}{l}\text { Arctic regions (used for all aspects of } \\
\text { Canadian Arctic regions) } \\
\text { Eskimos (used for Eskimauan Indians; } \\
\text { Esquimaux; Innuit; Inuit) }\end{array}$ \\
\hline 1992 & $\begin{array}{l}\text { Indians of North America - Mixed descent } \\
\text { Indians of North America - Canada } \\
\text { Metis }\end{array}$ & $\begin{array}{l}\text { Inuit - Canada } \\
\text { Inuit literature - Canada } \\
\text { Inuit poetry - Canada } \\
\text { Inuktitut imprints - Canada } \\
\text { Inuktitut language }\end{array}$ \\
\hline 1999 & Shift to Native peoples - Canada [CSH] & $\begin{array}{l}\text { Inuit - Canada [now an LCSH heading } \\
\text { and cancel the use of Eskimos for } \\
\text { Canada] }\end{array}$ \\
\hline 2002 & & Inuit - Clothing - Canada \\
\hline 2003 & ADD more First Nations & $\begin{array}{l}\text { Change Inuit land transfers - Canada to } \\
\text { Inuit - Land tenure - Canada } \\
\text { ADD more First Nations, e.g., } \\
\text { Tr'ondëk Hwëch'in Indians [from } \\
\text { Yukon] }\end{array}$ \\
\hline 2004 & & $\begin{array}{l}\text { Inuit in motion pictures } \\
\text { Inuit women artists - Canada }\end{array}$ \\
\hline 2005 & $\begin{array}{l}\text { Cancelled Indians of North America - } \\
\text { Mixed bloods and Indians of North America } \\
\text { - Mixed descendent [remains valid LSCH } \\
\text { heading] } \\
\text { Add Innu }\end{array}$ & $\begin{array}{l}\text { Inuit - Québec (Province) - Nunavik } \\
\text { Innu }\end{array}$ \\
\hline 2009 & $\begin{array}{l}\text { Native peoples, but use individual First } \\
\text { Nations wherever possible }\end{array}$ & $\begin{array}{l}\text { Folklore-Arctic regions } \\
\text { Inuit sign language } \\
\text { Inuksuit in Art }\end{array}$ \\
\hline 2011 & $\begin{array}{l}\text { Shift to Indigenous peoples by LCSH as the } \\
\text { Broader Term for Canada }\end{array}$ & Inuit authors - Canada \\
\hline
\end{tabular}


The most notable term evolution in CSH for the Arctic region was 'Inuit Canadian' which appeared in 1992. This shift occurred seven years earlier than the 1999 shift away from 'Indians of North America' that is still ongoing. Notable, also, is that ICLPL changed to 'Inuit' from 'Eskimo' in 1981 and ICLL made the same shift in 1985 - these changes occurred roughly a full decade earlier than the CSH. By comparison, $M L B I$ did not add 'Inuit' to its subject headings until the same year as the CSH change in 1992. CAD did not include 'Inuit' whatsoever until 2003.

Researchers must use multiple terms in full-text and controlled vocabulary database searches to ensure they find the most relevant results to their research. For example, a search using only 'Indigenous Peoples' as a term does not find as many results as the search string: (Aboriginal OR Eskimo OR “First Nations” OR Indian OR “Indigenous Peoples” OR Innu OR Inuit OR Métis OR “Native Peoples”). Controlled vocabulary in databases usually use U.S.centred terms. Therefore, 'Indians,' 'Eskimo,' 'Indigenous,' and 'Native Peoples' are usually the four terms researchers should use as a starting point to check subject headings, then 'Inuit,' 'Métis,' and 'First Nations' as Canadian-specific subject terms. The complex nature of full-text searching in legal databases requires all these terms, as well as individual nation and cultural terms specific to legal researchers' topics. Use of this strategy increases the likelihood of a comprehensive search that will retrieve all potentially relevant information. Stringing together historical and contemporary search terms in a general search is recommended to find the most comprehensive list of materials.

Law cataloguers and database vendors straddle professional rules for cataloguing and organising materials with researchers' needs in provision of access to content. Having a controlled vocabulary for subject headings helps with consistent treatment of both primary and 
secondary materials; however, the terms used by researchers will vary due to changing vernacular. Technological advances are improving researcher experiences to ensure relevant results are retrieved using proper phrasing for the most precise results possible. Graham and Prager (2012, p.24) noted that "interaction with ... vocabulary [in cataloguing and searching processes] has undergone dramatic transformation;" this is especially true in the technologicallydriven 21st Century where online databases increasingly feature smart-text, auto-fill, and autosuggestion searching features. However, cataloguers regularly use authorities and controlled vocabulary in creating their libraries' catalogue records and metadata. Research by Carter (2002, pp.21-22) showed that "keyword searching did not do a better job of retrieving for content than LC [Library of Congress] subject headings," suggesting that subject headings remain a basic key feature of cataloguing records and metadata for finding information even as databases get smarter.

The six law firm interviewees indicated that cataloguers in law firms rely heavily on copy cataloguing, wherever possible. Junior cataloguers are less likely to undertake original cataloguing, while senior cataloguers are more able to provide unique and historical information when composing catalogue records. The analysis presented in this chapter of search terms as they relate to subject headings can assist both new and experienced cataloguing staff in their cataloguing of resources. Bone and Lougheed (2018) described in detail how the Association of Manitoba Archives adapted LCSH to update generally outdated terminology in an effort for balancing access to resources for their user groups, using terms to accurately reflect the identity of Indigenous Peoples in a sensitive way, and choosing “... between official, legal, and socially and politically meaningful categories." Ultimately, the Association of Manitoba Archives project eliminated the intermediate hierarchical heading for 'Indians of North America,' but kept "the 
terms for Inuit, Métis, and for the individual First Nations groups...” while creating 'Indigenous Peoples' as the broadest subject headings (Bone and Lougheed, 2018, p.88).

LAC's Aboriginal consultation throughout the early- and mid- 2000s stressed the priority of rectifying Aboriginal subject heading deficiencies by stating that "issues of racism and ignorance are raised by present cataloguing standards and terminology" (Blake, Martin, and Pelletier, 2004, p.23). Webster and Doyle (2008, p.195) stressed the need to begin mitigation of ethnic, social, cultural, and geographic stereotypes and inaccuracies in library cataloguing because classification schemes, such as LCC and the Dewey Decimal Classification System, are used wholly or in part to create records at libraries around the world. As such, it is easy for flawed cataloguing and metadata to be spread globally. In fact, cataloguers often adopt LCSH exactly because of its widely accepted use; however, some cataloguers have "astutely noted the problematic history librarians and archivists in Canada have had with LCSH when attempting to describe resources created by or about Indigenous people." (Bone and Lougheed, 2018, p.84).

Table 6 provides suggested terminology along with working definitions for researchers and cataloguers to use from both historical and contemporary perspectives that categorise Indigenous Peoples in Canada. Cataloguers can use these terms to better understand researchers' needs and the necessity for both contemporary and historical terms when cataloguing library resources. 
Table 6: Working Definitions for Indigenous Peoples in Canada

\begin{tabular}{|l|l|}
\hline Term & Working Definition \\
\hline Aboriginal Peoples & $\begin{array}{l}\text { Used in the Constitution Act, 1982 to include all Indigenous } \\
\text { Peoples in Canada, '“' aboriginal peoples of Canada" includes } \\
\text { the Indian, Inuit and Métis peoples of Canada" (s. 35). }\end{array}$ \\
\hline Eskimo & $\begin{array}{l}\text { Outdated collective term for Indigenous Peoples in Canada's } \\
\text { Arctic Region. }\end{array}$ \\
\hline First Nations & $\begin{array}{l}\text { A term developed by Indigenous Peoples in the 1970s and is seen } \\
\text { as a preferred term by educators in 2017. However, Métis and } \\
\text { Inuit peoples are excluded. }\end{array}$ \\
\hline Indian & $\begin{array}{l}\text { Used in Canada to reflect those Indigenous Peoples with status } \\
\text { under the Indian Act. Historically, the term was used to describe } \\
\text { the Indigenous Peoples in Canada as was done in the BNA Act } \\
\text { and are defined in the Indian Act “Indian means a person who } \\
\text { pursuant to this Act is registered as an Indian or is entitled to be } \\
\text { registered as an Indian" (s. 2). }\end{array}$ \\
\hline Indians of North America & $\begin{array}{l}\text { Term from the Library of Congress Subject Headings used for } \\
\text { Indigenous Peoples in Canada. }\end{array}$ \\
\hline Indigenous Peoples & $\begin{array}{l}\text { Used to reflect international law respecting Indigenous Peoples. } \\
\text { Also, increasingly more popular to reflect Aboriginal Peoples } \\
\text { living in Canada. }\end{array}$ \\
\hline Inuit & $\begin{array}{l}\text { Indigenous Peoples living in Canada's North (Nunavut, North } \\
\text { West Territories, Quebec, and Labrador). Innu (separate group } \\
\text { located in Northeastern Quebec and Southern Labrador) is often } \\
\text { incorrectly included as part of Inuit. }\end{array}$ \\
\hline nations or tribes & $\begin{array}{l}\text { People of mixed ancestry between European settlers and } \\
\text { Indigenous Peoples in Canada. }\end{array}$ \\
\hline $\begin{array}{l}\text { Outdated collective term for all Indigenous Peoples in Canada } \\
\text { which some see as derogatory. }\end{array}$ \\
$\begin{array}{l}\text { N.B. need to use outdated/incorrect and current terminology } \\
\text { (e.g., Sarcee, Tsuut'ina Nation, Reserve 145, Sarsi, Tsuu T'Ina) }\end{array}$ \\
\hline Native Peoples
\end{tabular}

\section{Future Research}

The foundation for researching Canadian library cataloguing practices of materials related to Indigenous Peoples should flow from recommendations found in the 2017 CFLA report. Culturally-appropriate metadata should be integrated, or terminology changed, as appropriate, as part of indigenising initiatives across Canada. Comparing the Canadian example 
to other geographies - including other Arctic countries, Australia, and regional-local Indigenous communities globally - would provide an international context to Indigenous terms in different legal systems. Although the study described in this chapter specifically takes the Canadian perspective, Arctic researchers could use the same legal terminological analysis as a foundation for their own similar analyses, for example, in Greenland, Siberia, and Alaska, beginning with the terms 'Eskimo' and 'Inuit.'

Future analysis is also needed in evaluation of subject headings and other metadata used specifically within legal and interdisciplinary databases. Different vendors and editors organise primary materials in electronic databases using different forms of headings and metadata for Indigenous Peoples in Canada, but little is known about what this means in practice. For instance, how does the variation in subject headings and metadata used to classify and describe Canadian Indigenous Peoples relate to successful or unsuccessful retrieval yield results in popular electronic discovery services platforms such as those offered by EBSCO, ExLibris, and other vendors? Also, how is information literacy instruction impacted by subject heading and metadata variations, particularly in Arctic and Indigenous studies courses, and compared to general courses in history, political science, sociology, etc. where Arctic and Indigenous topics are covered?

\section{Conclusion}

Borrows and Rotman (2012, p.583) noted that "people adapt to changes within legal frameworks." Therefore, in Canada, the final shift from the collective term 'Aboriginal Peoples' to 'Indigenous Peoples' begins with the 2019 legislative changes introduced by Trudeau to work with Indigenous Peoples "to do away with legislation and policies built to serve colonial interests" (2018). This chapter aims to be a timely contribution to the ongoing Canadian and 
worldwide discussion about Aboriginal-Indigenous terminology, specifically for legal cataloguing and research in Arctic contexts. It advocates for a broader, global conversation that all law libraries and other libraries with law materials serving Arctic interests be responsible for developing best practices that effectively bridge the gap between historical and contemporary terminology for Indigenous Peoples.

Research for the current chapter involved a systematic analysis of terminology from legal indexes and subject headings related to Indigenous Peoples in Canada with concentration on the Arctic. Although the specific term 'Inuit,' formerly 'Eskimo,' is the collective term for Indigenous Peoples in the Canadian Arctic, controlled vocabulary in library catalogues and legal research requires the use of the larger collective terms analysed and included throughout this chapter. Clearly, as suggested by this chapter, contemporary and historical subject headings combined will continue to be needed by law cataloguers and legal researchers in Canada to effectively catalogue and search for content related to Indigenous Peoples. While the TRC and CFLA both call for improved terminology related to Canadian indigenous groups, historical terms for indigenous legal and Arctic research cannot be discarded from lexicon if the controversial history of Canada's colonial past are to remain in the Aboriginal-Indigenous social narrative.

\section{Endnote}

An earlier version of this chapter was presented at the 9th International Congress of Arctic Social Sciences (ICASS-IX), 8-12 June 2017, Umeå, Sweden. The presentation has been archived in the University of Calgary repository at: https://prism.ucalgary.ca/handle/1880/52147. 


\section{References}

Barber, K., ed., 2004. The Canadian Oxford dictionary. 2nd ed. [e-book] Toronto: Oxford University Press.

Blake, D., Martin, L., and Pelletier, D., 2004. Report and recommendations of the consultation on Aboriginal resources and services. [pdf] Ottawa: Library and Archives Canada. Available at: < https://www.collectionscanada.gc.ca/obj/020008/f2/020008-7000-e.pdf> [Accessed 15 October 2018].

Bone, C., and Lougheed, B., 2018. Library of Congress Subject Headings related to Indigenous Peoples: Changing LCSH for use in a Canadian archival context. Cataloging and Classification Quarterly, 56(1), pp.83-95. https://doi.org/10.1080/01639374.2017.1382641.

Borrows, J.J., and Rotman, L.J., 2012. Aboriginal legal issues: Cases, materials, and commentary. 4th ed. Markham, Ontario: LexisNexis.

British North America Act, 1867. 30-31 Vict., c. 3 (United Kingdom). [pdf] Available at: $<$ http://www.legislation.gov.uk/ukpga/1867/3/pdfs/ukpga_18670003_en.pdf> [Accessed 15 October 2018].

Budget Implementation Act, 2019, No 1. SC 2019, c 29. Available at < https://lawslois.justice.gc.ca/eng/AnnualStatutes/2019_29> [Accessed 22 October 2019].

Campbell, N., 1996. Canadian legal bibliography. Canadian Law Libraries, 21(1), pp.241-250.

Campbell, N., 1997. A survey of Canadian legal bibliography. In: M. Foote, ed., Law reporting and legal publishing in Canada: A history. CALL/ACBD occasional paper, no. 2. Kingston, Ontario: Canadian Association of Law Libraries. pp.1-15.

Canadian abridgment: A digest of decisions of the provincial and dominion courts, including appeals therefrom to the privy council, but excluding decisions based on the Quebec Civil Code, 1935. Toronto: Burroughs \& Company Ltd. and Carswell Company Ltd.

Canadian abridgment: Case digests. 3rd ed., 2003. Toronto: Carswell Company Ltd.

Canadian abridgment consolidation: A digest of all Canadian cases reported in the years 193655, 1956. Toronto: Burroughs \& Company Ltd. and Carswell Company Ltd.

Canadian abridgment: Index to Canadian legal literature, 1981-1986. Toronto: Carswell Company Ltd.

Canadian abridgment: Index to Canadian legal literature. 2nd ed., 1987-2017. Toronto: Carswell Company Ltd. 
Canadian annual digest, 1892-1961. Aurora, Ontario: Canada Law Book.

Canadian Federation of Library Associations, 2017. Truth and reconciliation report and recommendations [pdf]. Available at: <http://cfla-fcab.ca/wp-content/uploads/2017/04/ Truth-and-Reconciliation-Committee-Report-and-Recommendations.pdf> [Accessed 15 October 2018].

Canadian Library Association, Committee on Canadian Subject Headings, 1968. A list of Canadian subject headings. Ottawa: Canadian Library Association.

Canadian Library Association, Technical Services Section, 1966. A list of Canadian subject headings. Ottawa: Canadian Library Association.

Carter, N.C., 2002. American Indians and law libraries: Acknowledging the Third Sovereign. Law Library Journal, 94(1), pp.7-26.

Chan, L.M., 2007. Cataloging and classification: An introduction. 3rd ed. Lanham, MD: Scarecrow Press.

Compass Law, 2017. Compass, vLex, and Justia bring a world of legal information to Canada. [online] Available at: <http://disruptlaw.ca/> [Accessed 15 October 2018].

Constitution Act 1982, being schedule B to the Canada Act 1982, c. 11 (United Kingdom). [pdf] Available at:

<http://www.legislation.gov.uk/ukpga/1982/11/pdfs/ukpga_19820011_en.pdf> [Accessed 15 October 2018].

CTV News Calgary. National Indigenous Peoples Day. [Video Interview] Available at: $<$ https://calgary.ctvnews.ca/video?clipId=1423012\&binId=1.1201941\&playlistPageNum $=1>$ [Accessed 15 October 2018].

Denton, V.K. (1997). Canadian law publishers: A look at the development of the legal publishing industry in Canada. In M. Foote, ed., Law reporting and legal publishing in Canada: A history. CALL/ACBD occasional paper, no. 2. Kingston, Ontario: Canadian Association of Law Libraries. pp.16-42.

Department of Indian Affairs and Northern Development Act, Revised Statutes of Canada 1985, c. I-6 (Canada). [pdf] Available at: 〈https://laws-lois.justice.gc.ca/PDF/I-6.pdf> [Accessed 15 October 2018].

Digest of Canadian Case Law, 1900-1926. Toronto: The Carswell Company Ltd. 
Environics Institute for Survey Research, 2016. Canadian public opinion on Aboriginal Peoples: Final report. Toronto: Environics Institute for Survey Research. [pdf] Available at: $<$ https://www.environicsinstitute.org/docs/default-source/project-documents/publicopinion-about-aboriginal-issues-in-canada-2016/final-report.pdf?sfvrsn=30587aca_2> [Accessed 15 October 2018].

Foote, M., 1994. The new Canadian abridgment: A review article. Legal Reference Services Quarterly, 14(1-2), pp.5-22. https://doi.org/10.1300/J113v14n01_02.

Garner, B.A., ed., 2014. Black's law dictionary. 10th ed. St. Paul, MN: Thomson Reuters.

Ginsberg, J., 1988. A note on the KF Classification Modified for use in Canadian law libraries. In: J.N. Fraser, ed., Law libraries in Canada: Essays to honour Diana M. Priestly. Toronto: Carswell Company Ltd. pp.159-161.

Graham, S.R., and Prager, G., 2012. Enriching the vocabulary of law: New legal subject headings. AALL Spectrum, 17(2), pp.24-25. Available at: <https://digitalcommons.law.uga.edu/law_lib_artchop/30/> [Accessed 15 October 2018].

Indian Act, Statutes of Canada 1876, c. 18 (Canada). [online] Available at: <https://www.aadncaandc.gc.ca/eng/1100100010264/1100100010266> [Accessed 15 October 2018].

Indian Act, Revised Statutes of Canada 1985, c. I-5 (Canada). [pdf] Available at: <https://lawslois.justice.gc.ca/PDF/I-5.pdf> [Accessed 15 October 2018].

Indian and Northern Affairs Canada, Communications Branch, 2002. Words first: An evolving terminology relating to Aboriginal Peoples in Canada. [pdf] Available at <http://publications.gc.ca/collections/Collection/R2-236-2002E.pdf> [Accessed 15 October 2018].

Indian Residential Schools Settlement. 2006. Indian Residential Schools Settlement: Official Court Notice. [online] Available at: <www.residentialschoolsettlement.ca/english_index.html> [Accessed 22 January 2019].

Indigenous and Northern Affairs Canada, 2017. First Nations. [online] Available at: <https://www.rcaanc-cirnac.gc.ca/eng/1100100013791/1535470872302> [Accessed 15 October 2018].

Indigenous Corporate Training, Inc., 2016. Indigenous Peoples: A guide to terminology: Usage tips and definitions. [online] Available at: <https://www.ictinc.ca/aboriginal-peoples-aguide-to-terminology $>$ [Accessed 15 October 2018].

Kam, D.V., 2007. Subject headings for Aboriginals: The power of naming. Art Documentation: Bulletin of the Art Libraries Society of North America, 26(2), pp.18-22. https://doi.org/10.1086/adx.26.2.27949465. 
Lee, D., 2011. Indigenous knowledge organization: A study of concepts, terminology, structure and (mostly) Indigenous voices. Partnership: The Canadian Journal of Library and Information Practice and Research, 6(1). http://dx.doi.org/10.21083/partnership.v6i1.1427.

Library and Archives Canada, 2012. Terminology guide: research on Aboriginal heritage. [pdf] Available at: <http://publications.gc.ca/collections/collection_2017/bac-lac/SB4-452012-eng.pdf > [Accessed 15 October 2018].

Library and Archives Canada, 2013 (modified 30 December 2016). Update on subject headings for Aboriginal peoples in Canada. [online] Available at: <http://www.baclac.gc.ca/eng/news/Pages/Archived\%20news/2013/subject-headings-aboriginalpeoples.aspx> [Accessed 15 October 2018].

Library and Archives Canada, 2016. About Canadian Subject Headings (CSH). [online] Available at: <https://www.bac-lac.gc.ca/eng/services/canadian-subject-headings/Pages /about-csh.aspx > [Accessed 15 October 2018].

Library of Congress, 1988. Cataloging Service Bulletin, 41(Summer). [pdf] Available at: $<$ https://www.loc.gov/cds/PDFdownloads/csb/CSB_041.pdf> [Accessed 15 October 2018].

Lougheed, B., Moran, R., and Callison, C., 2015. Reconciliation through description: Using metadata to realize the vision of the National Research Centre for Truth and Reconciliation. Cataloging and Classification Quarterly, 53(5-6), pp. 596-614. https://doi.org/10.1080/01639374.2015.1008718.

Maritime law book index, Alberta reports, 1976-2016. Fredericton, Nova Scotia: Maritime Law Book.

Matthews, S., 2016. Maritime Law Book acquired. SLAW: Canada's Online Legal Magazine, [blog] 1 November. Available at: <http://www.slaw.ca/2016/11/01/maritime-law-bookacquired/?highlight=maritime\%20law\%20book> [Accessed 15 October 2018].

Moulaison Sandy, H., and Bossaller, J., 2017. Providing cognitively just subject access to Indigenous knowledge through knowledge organization systems. Cataloging and Classification Quarterly, 55(3), pp.129-152. https://doi.org/10.1080/01639374.2017.1281858.

National Library of Canada, 1985. Canadian Subject Headings. 2nd ed. Ottawa: National Library of Canada.

Nisga'a Final Agreement 2000, c. 7 (Canada). [pdf] Available at: <https://lawslois.justice.gc.ca/PDF/N-23.3.pdf> [Accessed 17 October]. 
Olson, H.A., 2002. The power to name: Locating the limits of subject representation in libraries. Dordrecht, Netherlands: Kluwer Academic Publishers.

Olson, H.A., and Schlegl, R., 2001. Standardization, objectivity, and user focus: A meta-analysis of subject access critiques. Cataloging and Classification Quarterly, 32(2), pp.61-80. https://doi.org/10.1300/J104v32n02_06.

Quigley-Jones, T., ed., 1994. KF Classification, modified for use in Canadian law libraries: KF modified. North York, Ontario: York University Law Library.

Retzlaff, S., 2005. What's in a name? The politics of labelling and native identity constructions. [pdf] Canadian Journal of Native Studies, 25(2), pp. 609-626. Available at:

<http://www3.brandonu.ca/cjns/25.2/cjnsv25no2_pg609-626.pdf> [Accessed 15 October 2018].

Rodrigues, G.P., 2016. The passing of Maritime Law Book - the end of an era. SLAW: Canada's Online Legal Magazine, [blog] 22 August. Available at:

<http://www.slaw.ca/2016/08/22/the-passing-of-maritime-law-book-the-end-of-anera/?highlight=maritime\%20law\%20book $>$ [Accessed 15 October 2018].

Royal Proclamation, October 7, 1763, Revised Statutes of Canada 1985, Appendix II, No. 1 (Canada). [pdf] Available at: <http://publications.gc.ca/collections/collection_2014/loisstatutes/YX44-1985\%209-1.pdf> [Accessed 15 October 2018].

Schweitzer, A., ed., 1992. Canadian Subject Headings. 3rd ed. Ottawa: National Library of Canada.

Scott, M., ed., 1961-2006. Index to Canadian legal periodical literature. Montréal: Canadian Association of Law Libraries.

Silverstein, M., 2008. The first seventy years, The Canadian abridgment. 3rd ed. Toronto: Carswell Company Ltd. pp. xi-xv.

Tarulli, L., 2007. Native Peoples v. Indigenous Peoples v. Aboriginals ... Are any of the terms really any good? The Cataloguing Librarian, [blog] 27 September. Available at: $<$ https://laureltarulli.wordpress.com/2007/09/27/native-peoples-v-indigenous-peoples-vaboriginalsare-any-of-the-terms-really-any-good/> [Accessed 15 October 2018].

Tomren, H., 2003. Classification, bias and American Indian materials. [pdf] Available at: $<$ http://ailasacc.pbworks.com/f/BiasClassification2004.pdf> [Accessed 17 October 2018].

Trudeau, J., 2018. Rights of Indigenous Peoples. House of Commons debates, official report (Hansard), 48(264). [Online Transcript] 42nd Parliament, 1st Session, 14 February. Ottawa: Parliament of Canada. Available at:

<http://www.ourcommons.ca/DocumentViewer/en/42-1/house/sitting-264/hansard> [Accessed 17 October 2018]. 
Truth and Reconciliation Commission of Canada, 2015. Truth and Reconciliation Commission of Canada: Calls to action. [pdf] Winnipeg, Manitoba: Truth and Reconciliation Commission of Canada. Available at: <http://nctr.ca/assets/reports/Calls_to_Action_English2.pdf> [Accessed 17 October 2018].

United Nations. 2008. United Nations declaration on the rights of Indigenous Peoples. [pdf] Available at: 〈https://www.un.org/esa/socdev/unpfii/documents/DRIPS_en.pdf > [Accessed 17 October 2018].

Webster, K., and Doyle A., 2008. Don't class me in antiquities! Giving voice to Native American materials. In: K.R. Roberto, ed., Radical cataloging: Essays at the front. Jefferson, NC: McFarland \& Co. pp.189-97. 